\title{
Diagnostic value of blood urea and bilirubin levels determination in patients with gastroduodenal zone diseases
}

\author{
I. B. Zhakun, O. O. Sorokopud, L. M. Strilchuk, Z. M. Kit, M. O. Kondratyuk \\ Danylo Halytsky Lviv National Medical University, Ukraine
}

Key words: urea, bilirubin, Helicobacter pylori (HP), gastroduodenal diseases, diseases eradication, biliary tract diseases, pneumonia.

\section{Zaporozhye} medical journal 2017; 19 (6), 758-763

DOI:

10.14739/2310-1210. 2017.6.114717

E-mail:

vi-2007@ukr.net
The study of relationships of urea and bilirubin blood levels in patients with Helicobacter pylori associated gastroduodenal pathology (HP-aGDP) has the considerable relevance for clinicians, since these indicators represent the status and function of the gastroduodenal zone.

The aim of this study was to estimate changes of bilirubin and urea blood levels in patients with HP-aGDP before and after treatment. Materials and methods. Our study has included 59 patients of the main group with different HP-aGDP and 44 patients of the control group with community-acquired pneumonia (CAP).

Results. In patients with HP-aGDP the doubly severe reduction of urea concentration was observed in significantly greater number of patients, while half of the patients in the controls had an increase of its level by $10.4 \%$. The bilirubin concentration decrease was more pronounced $(37.1 \%$ vs. $3.5 \%)$ and significant $(P<0.05)$ in patients with HP-aGDP. Its rate depended on the dynamics of urea exactly in patients with HP-aGDP and it was more pronounced in case of urea reduction $(P<0.05)$. Thus, the revealed association of bilirubin and urea levels changes, namely their decrease owing to the treatment, was inherent only to patients with HP-aGDP unlike to the patients with CAD. We also determined the involvement of lipid, carbohydrate and protein metabolism, electrolytes, composition of blood in the processes of local and systemic inflammation caused by HP and its relationship with adaptive reactions, which generally depended on other individual characteristics of patients in the study group (age, duration of disease, ulcer size, etc.).

Conclusions. The monitoring of urea and bilirubin blood levels in patients especially with HP-aGDP during the eradication has a specific diagnostic and prognostic value. The bilirubin level in such cases reflects the severity of cholestasis, inflammatory lesions of the duodenal mucosa, comorbid hepatobiliary disease, while the urea level reduction may be an additional criterion of efficacy of HP eradication.
Ключові слова:

сечовина,

бімірубін,

Helicobacter pylori,

хвороби

гастродуоденальної

зони,

ерадикація,

гепатобіліарна

патологія,

пневмонія.

Запорізький

медичний

журнал. - 2017. -

T. 19, № 6(105).

C. $758-763$

\section{Аіагностичне значення визначення вмісту сечовини та бімірубіну крові в пацієнтів із хворобами гастродуоденальної зони}

\section{І. Б. Жакун, О. О. Сорокопуд, А. М. Стрільчук, З. М. Кіт, М. О. Кондратюк}

Вивчення взаємозв'язків умісту сечовини та білірубіну крові в пацієнтів із HP-aGDP має істотне значення для клініцистів, оскільки ці показники відбивають стан і функцію органів гастродуоденальної зони, їхні зміни можуть мати вагоме значення в оцінюванні стану подібних пацієнтів.

Мета роботи - оцінювання змін вмісту білірубіну й сечовини крові, інших параметрів метаболізму, показників крові до та після лікування пацієнтів із HP-aGDP.

Матеріали та методи. Дослідження включало 59 пацієнтів основної групи з різними HP-aGDP i 44 особи контрольної групи з СAP.

Результати. Динаміка змін рівня сечовини крові в пацієнтів із HP-aGDP і пацієнтів із САР значно відрізнялась: удвічі більш виражене зниження концентрації сечовини спостерігалось у більшої кількості пацієнтів основної групи, в той час як у половини пацієнтів контрольної групи визначалось збільшення ії рівня на 10,4 \%. Зниження концентрації білірубіну було вираженішим $(37,1 \%$ проти $3,5 \%$ ) та істотнішим ( $<$ < 0.05) у пацієнтів із HP-aGDP, ніж у контрольній групі. Ступінь його зниження залежав від динаміки вмісту сечовини саме у хворих із HP-aGDP: він був вираженішим у випадку зниження рівня сечовини $(p<0.05)$. Отже, виявлена асоціація змін умісту білірубіну та сечовини крові, а саме їхнє зниження внаслідок лікування, притаманне тільки пацієнтам із HP-aGDP на відміну від пацієнтів із CAP, що свідчить про залученість азотного метаболізму та функцій печінки в патогенезі цієї нозології. Нами також виявлена залученість жирового, вуглеводного та білкового обміну, електролітів, складу, функції крові до процесів місцевого та системного запалення, що викликане НР, його взаємозв'язок із реакціями адаптації, що загалом істотно залежало від інших індивідуальних характеристик пацієнтів основної групи (вік, тривалість хвороби, розмір виразкового дефекту тощо).

Висновки. Моніторинг рівнів сечовини та білірубіну крові саме в пацієнтів із HP-aGDP протягом ерадикації має специфічне діагностичне та прогностичне значення. Рівень білірубіну в таких випадках показує тяжкість холестазу, запального ураження слизової оболонки дванадцятипалої кишки, актуальність супутньої гепатобіліарної патології, водночас як зниження рівня сечовини може бути додатковим критерієм ефективності ерадикації НР.

Ключевые слова: мочевина, билирубин, Helicobacter pilori, болезни гастродуоденальной зоны, эрадикация, гепатобилиарная патомогия, пневмония.

\section{Аиагностическое значение определения содержания мочевины и бияирубина крови у пациентов с болезнями гастродуоденальной зоны}

\section{И. Б. Жакун, Е. А. СорокопуА, А. Н. Стрильчук, З. М. Кит, М. А. Кондратюк}

Изучение взаимосвязей уровней мочевины и билирубина крови у пациентов c HP-aGDP имеет существенное значение для клиницистов, так как эти показатели отражают состояние и функцию органов гастродуоденальной зоны, их изменения могут иметь большое значение в оценке состояния пациентов. 
Цель работы - оценка изменений содержания билирубина и мочевины крови, других параметров метаболизма и показателей крови до и после лечения пациентов с HP-aGDP.

Материалы и методы. Исследование включало 59 пациентов основной группы с различными HP-aGDP и 44 пациента контрольной группы с САР.

Результаты. Динамика изменений концентрации мочевины крови у пациентов с HP-aGDP и пациентов с CAP значительно отличалась: вдвое более выраженное снижение ее содержания наблюдалось у значительно большего числа пациентов основной группы, в то время как у половины пациентов контрольной группы определялось увеличение ее уровня на 10,4 \%. Снижение концентрации билирубина было более выраженным $(37,1 \%$ против 3,5 \%) и достоверным (p<0,05) у пациентов c HP-aGDP, чем в контрольной группе. Выраженность снижения билирубина зависела от динамики содержания мочевины именно у больных с HP-aGDP: оно было более выраженным в случае снижения уровня мочевины (p<0,05). Таким образом, выявленная ассоциация изменений содержания билирубина и мочевины, а именно их снижение в результате лечения, присуще только пациентам с HP-aGDP в отличие от пациентов с CAP, что свидетельствует о вовлеченности азотного метаболизма и функций печени в патогенезе данной нозологии. Нами также обнаружена вовлеченность жирового, углеводного и белкового обмена, электролитов, состава и функций крови в процессы местного и системного воспаления, вызванного НР, его взаимосвязь с реакциями адаптации, что достоверно зависело от других индивидуальных характеристик пациентов основной группы (возраст, продолжительность болезни, размер язвенного дефекта и так далее).

Выводы. Мониторинг уровней мочевины и билирубина крови именно у пациентов с HP-aGDP в течение эрадикации имеет специфическое диагностическое и прогностическое значение. Уровень билирубина в таких случаях отражает тяжесть холестаза, воспалительного поражения слизистой оболочки двенадцатиперстной кишки, наличие сопутствующей гепатобилиарной патологии, в то время как снижение уровня мочевины может быть дополнительным критерием эффективности эрадикации НР.

It is well-known that gastric and duodenal disorders associated with Helicobacter pylori (HP) infection may have an impact on the content of ammonia and urea not only in gastric juice, but also in blood through urease activity of this microorganism [1]. On the other hand, blood bilirubin level is an important indicator, which characterizes the pigment metabolism, the state of biliary system, the function of organs of gastroduodenal zone, the intensity and effectiveness of antioxidant protection [2,3]. Therefore, the determination of these parameters and further study the mutual influence or associations of bilirubin and urea of the blood in patients with HP-associated gastroduodenal pathology (HP-aGDP) is the considerable subject of interest for clinicians, resulting in expediency of our study.

\section{Purpose}

The aim of this study was to estimate changes of bilirubin and urea blood levels and other metabolic parameters and blood indices in patients with HP-aGDP before and after treatment.

\section{Materials and methods}

Overall, we have examined 103 patients with internal diseases. The main group included 59 patients with HP-aGDP with the average age of $32.2 \pm 1.6$ years. Mean disease duration was $2.9 \pm 0.53$ years. Gastric or duodenal ulcer was diagnosed in $54 \%$ of patients (the average ulcer size was $0.58 \pm 0.05 \mathrm{~cm})$; other participants had chronic gastroduodenitis (14\%), duodenitis (12\%), gastritis (5\%), non-ulcer dyspepsia (7\%) and gastroesophageal reflux disease (8\%). According to recommendations in the 4th edition of the Maastricht Consensus Report all patients underwent eradication antibiotic therapy. The control group included 44 patients with community-acquired pneumonia (CAP) with the average age of $23.8 \pm 1.7$ years, treated with etiotropic antibiotic therapy (aminopenicillins and/or macrolides). Consequently, we compared changes in the concentration of bilirubin and blood urea in similar conditions (infectious nature of the disease, syndromes of local and systemic inflammation, and the use of similar groups of antibiotics). The study did not include people with liver or kidney dysfunction and changes in the parameters of nitrogen metabolism.

Total bilirubin count and its fractions in the serum was examined by colorimetric diazo method (normal 8.5-20.5 $\mathrm{mcmol} / \mathrm{L}$ ), urea - by enzymatic method (normal 2.5-8.3 $\mathrm{mcmol} / \mathrm{L}$ ). Patients were divided into three groups by the level of urea: up to $5.0 \mathrm{mmol} / \mathrm{L}$ (I); 5.0-5.4 mmol/L (II); $5.5 \mathrm{mmol} / \mathrm{L}$ or more (III). Results were processed by mathematical statistics, the level of significance was set to $P<0.05$, the degree of linear correlation assessed using Pearson's correlation coefficient ( $r$ ).

\section{Results and discussion}

We have found and analysed significant correlation between the studied biochemical and blood parameters in patients with HP-aGDP in order to obtain an overall characteristic of the main group. The persistent correlation of patients' age of the study group and duration of disease proved to be obvious $(r=0.475)$. Increased levels of triglycerides $(r=0.387)$ and cholesterol of very low density lipoprotein $(r=0.387)$, greater erythrocyte sedimentation rate $(r=0.378)$ and the increased number of eosinophils $(r=0.356)$ were often detected in older patients, what can generally display different aspects and severity of both local and systemic inflammation.

Direct correlation between urea and cholesterol $(r=0.373)$, cholesterol of very low density lipoprotein $(r=0.399)$, which have been determined, may also be an evidence of lipid metabolism involvement in the processes of systemic inflammation, particularly due to HP. In return, our data show that the increase of creatinine level was associated with higher levels of high density lipoprotein cholesterol $(r=0.316)$. An interesting fact was a positive association of the urea level with disease duration $(r=0.394)$, which may indirectly indicate a greater prevalence of HP-infection in patients with long course of HP-aGDP. Direct correlation of the urea level $(r=0.328)$, blood creatinine $(r=0.308)$ with glucose levels may be associated with older age of patients, comorbid pathology or pathophysiological changes in the function of pancreas.
Запорожский медицинский журнал. - 2017. T. 19, № 6(105). C. $758-763$ 


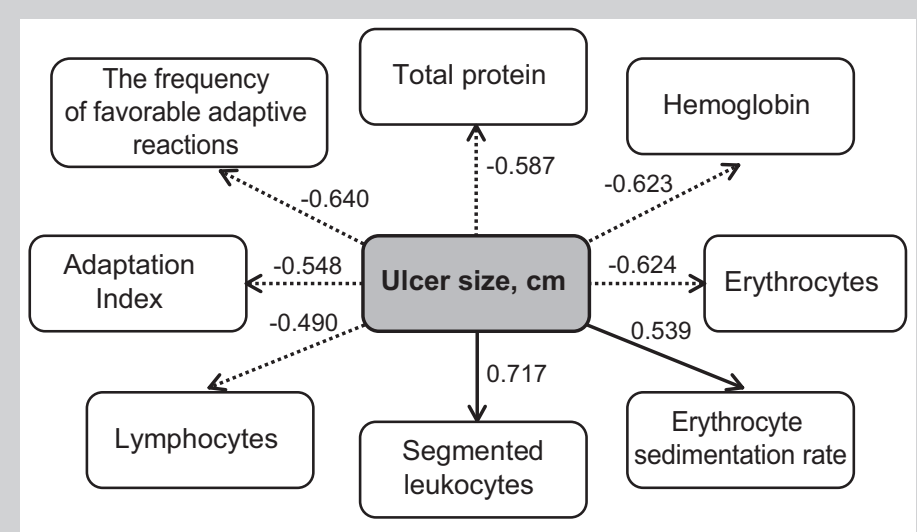

$\longrightarrow$ - direct correlations; $\quad \cdots \cdot \rightarrow-$ inverse correlations

Fig. 1. Direct and inverse linear correlations (by using of the Pearson correlation coefficient $-r$ ) between the ulcer size, blood count parameters, biochemical indicators and general nonspecific adaptive reactions in patients of the main group.

Inverse correlation of the urea concentration $(r=-0.366)$ and creatinine $(r=-0.437)$ with the number of white blood cells may indicate the peculiarities of leukocyte reactivity in the processes of local and systemic inflammation caused by HP. Also, urea concentration significantly positively correlated with concentrations of potassium and sodium $(r=0.363$; $r=0.425$ ) that can generally illustrate changes of electrolyte balance in patients with HP-aGDP. Increased potassium in blood serum may reflect the degree of tissue damage as a result or directly during inflammation or renin-angiotensin system activity reduction, and increased sodium level is often caused by loss of water containing little salt, resulting from vomiting with varying degrees of severity - a major specific symptom in patients with HP-aGDP.

A significant correlation between bilirubin and total blood protein levels $(r=0.521)$ can be complex reflection of liver function. Positive correlation between bilirubin concentration and the age of patients looks natural $(r=0.539)$, which indicates age-related changes of the liver function. Relationship between bilirubin level and blood monocyte count $(r=0.369)$ shows one of the parts of its production, namely, the conversion of heme into biliverdin involving macrophages.

According to many studies $[4,5]$ it is known that free bilirubin has marked antioxidant properties due to its ability to prevent lipid peroxidation of cell membranes and membrane protein oxidation, showing particular tropism for nerve tissue and heart muscle. Thus, according to the findings of M. K. Akboga, U. Canpolat, A. Sahinarslan et al. in 2015, serum bilirubin has significant inverse correlation with specific and non-specific markers of systemic inflammation such as C-reactive protein, a neutrophil and lymphocyte ratio (NLR) etc. allowing us to consider its concentration as a predictor to prevent the development of atherosclerosis, ischemic heart disease, systemic inflammation. Our study can illustrate these properties of free bilirubin as inverse correlation of its level with segmented neutrophil count $(r=-0.358)$ and direct one with lymphocyte count. The direct significant correlation of bilirubin concentration with adaptation index $(r=0.326)$ and the frequency of favourable adaptive reactions $(r=0.339)$ seems quite logical and natural taking into account its antioxidant and anti-inflammatory properties. This also may explain the inverse relationship of bilirubin level and the size of ulcer ( $r=-0.562)$, which we have defined, that is especially marked after eradication.

Significant correlations were most frequently diagnosed between the size of ulcer and other indicators. Thus, the presence and extent of HP-associated lesions of gastric or duodenal mucosa were inversely correlated with the age of patients $(r=-0.371)$ and directly correlated with the frequency of antibiotic therapy $(r=0.528)$, i.e. mucosal ulceration in our study was more often encountered in younger patients, which implies greater frequency of prescribed eradication therapy. Also, increased degree of lesion, more severe medical conditions were associated with an increase in blood glucose $(r=0.325)$, which may also be associated with older age of patients that was also positively correlated with blood glucose level $(r=0.329)$ or metabolic syndrome manifestations. Increased ulcers size was significantly associated with a decrease in total protein $(r=-0.587)$, probably as a manifestation of associated protein-producing liver function disorder (Fig. 1).

Larger defects in patients with HP-aGDP also had significant inverse correlation with hemoglobin and erythrocyte count $(r=-0.623 ; r=-0.624)$ due to greater frequency of current or previous haemorrhagic complications. Significant erythrocyte sedimentation rate increase in patients with larger ulcers $(r=0.539)$ turned out to be logical due to greater severity of inflammation, which is probably also related to a significant increase in segmented neutrophil count ( $r=0.717)$. Instead, increasing ulcer severity leads to significant reduction in lymphocyte count and adaptation index $(r=-0.490 ; r=-0.548)$, which is clearly associated with increasing frequency of adverse adaptive reactions $(r=-0.589)$. In our opinion, inverse significant correlation of the degree and size of ulceration of gastric and duodenal mucosa with blood monocyte count after eradication $(r=-0.611)$ is important, because low levels of the latter may be indirect evidence of regenerative processes failure and healing of ulcerative lesion caused by HP [6].

Then we used different ways to actually analyse and compare the dynamics of urea and blood bilirubin concentrations over time following the treatment in patients with HP-aGDP and CAP.

Differences in the frequency of different levels of blood urea were observed both before and after treatment in the main and control groups. Before treatment (Fig. 2) by the level of urea was most often determined as $\geq 5.5 \mathrm{mmol} / \mathrm{L}$ $(42.4 \pm 6 \%)$ in patients with HP-aGDP, while patients in the control group before treatment often referred to the I subgroup by the level of urea $(45.5 \pm 8 \%)$.

The amount of urea of $5.0-5.4 \mathrm{mmol} / \mathrm{L}$ was diagnosed significantly less frequently before treatment both in the study and control groups $(P<0.05)$ (Fig. 2). It should be noted that after treatment the number of patients in the II subgroup in terms of urea was significantly lower in the controls compared with the rate in the I and III subgroups $(P<0.05)$.

The frequency of urea different levels after treatment differed in the study and control groups. One of the similarities was that the number of patients in the I subgroup increased both in the main and the control groups $(7.6 \%$ and $6.9 \%)$. The rate of urea concentration of $5.0-5.4 \mathrm{mmol} / \mathrm{L}$ increased slightly in the study group, but it decreased in the controls by $6.9 \%$. The main difference was that urea concentration of $\geq 5.5 \mathrm{mmol} / \mathrm{L}$ was detected 1.3 times less in patients of 


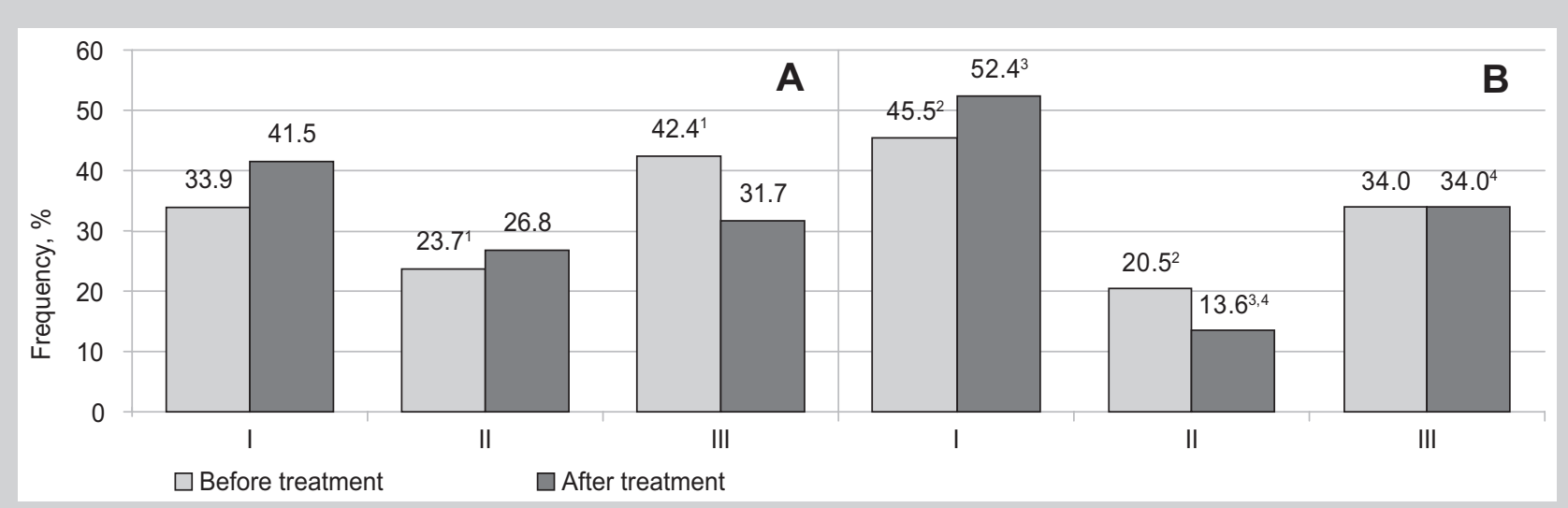

Fig. 2. The dynamics of the frequency of different urea levels (I, II, III subgroup) in patients with HP-aGDP (A) and CAP (B).

The differences are statistically significant $(P<0.05)$ between the frequency of different levels of urea:

I I and II subgroups before the treatment in patients with HP-aGDP; ${ }^{2}$ I and II subgroups before the treatment in patients with CAP;

: I and II subgroups after the treatment in patients with CAP; $4:$ II and III subgroups after the treatment in patients with CAP.

the main group than it was before treatment, while the rate remained unchanged in the III subgroup of the controls (Fig. 2). Thus, in contrast to the control group, the rate of urea concentration of $\geq 5.5 \mathrm{mmol} / \mathrm{L}$ decreased after treatment in patients with HP-aGDP, and the number of patients in the II subgroup remained almost unchanged, which may be indirect evidence of greater severity and intensity of blood urea concentration reduction than in patients with CAP.

The mean level of urea decreased by $3.3 \%$ in the main group (by $0.18 \mathrm{mmol} / \mathrm{L}$ ) and its decrease was twice as little in the controls (by $0.09 \mathrm{mmol} / \mathrm{L}$ ). Generally, the number of patients in the study group, whose level of urea decreased as a result of the treatment, was significantly greater compared with patients, whose level increased: its level decreased on an average of $0.46 \mathrm{mmol} / \mathrm{L}$ in $67 \%$ of the main group patients $(P<0.05)$, and it slightly increased by $0.64 \mathrm{mmol} / \mathrm{L}$ in the rest (33\%). In contrast to the above mentioned, mean urea concentration decreased slightly (by $1.8 \%$ ) only in half of the patients $(52.3 \%)$ in the control group, while in $47.7 \%$ of patients with CAP its level increased by $10.4 \%$ (by $0.97 \mathrm{mmol} / \mathrm{L}$ ), apart from that the changes were insignificant. Thus, reduction of urea in patients with HP-aGDP after treatment was more specific, marked and significant compared to the control group.

Assessing changes in the mean concentrations of blood bilirubin of patients with HP-aGDP and controls in the settings of different dynamics of urea due to treatment, it should be noted that they all occurred within the physiological norm. Initial median bilirubin concentration in the study group patients was $15.03 \mathrm{mcmol} / \mathrm{L}$, and after treatment it was $11.60 \mathrm{mcmol} / \mathrm{L}$. Mean level of bilirubin was determined as $9.04 \mathrm{mcmo} / \mathrm{L}$ before treatment and $8.40 \mathrm{mcmol} / \mathrm{L}$ after treatment in controls.

Blood bilirubin decreased after treatment in both main and control groups, but this process largely depended on nosology. Bilirubin decreased significantly in HP-aGDP patients by $23.1 \%$ (by $3.44 \mathrm{mcmol} / \mathrm{L}$ ) compared with the initial level, whereas in the control group its decline was 3.2 times smaller (only by $7.2 \%$ ) and insignificant.

The analysis of changes in the level of bilirubin in patients of the study and control groups with regard to dynamics (increase or decrease) in the urea level proved to be of greater interest (Fig. 3).
Mean level of blood bilirubin decreased significantly by $37.1 \%(6.06 \mathrm{mcmol} / \mathrm{L})$ in the main group compared to its initial level specifically in patients with decrease of urea $(P<0.05)$, whereas it remained almost unchanged in those with increased levels of urea (Fig. 3). Moreover, the percentage of bilirubin reduction in HP-aGDP patients in the settings of urea reduction was significantly greater than in patients with an increase in its' concentration $(P<0.05)$. This reported information may indicate a direct dependence of the bilirubin reduction intensity on the dynamics in the level of blood urea, namely, on its reduction in HP-aGDP patients after eradication.

Instead, in contrast to our results in the main group, other changes in blood bilirubin occurred in patients with CAP depending on the dynamics of urea (Fig. 3). Bilirubin just slightly decreased by $3.5 \%$ (by $0.30 \mathrm{mcmol} / \mathrm{L} ; \mathrm{P}>0.05$ ) in the settings of decreasing level of urea, while bilirubin levels decreased by $10.4 \%$ (to $0.97 \mathrm{mcmol} / \mathrm{L} ; \mathrm{P}>0.05$ ) when urea concentration increased. Therefore, the level of bilirubin in patients with CAP did not depend on the dynamics of blood urea, and its concentration decreased significantly in the settings of the urea level reduction in the main group of patients.

An interesting and indicative was the fact that the reduction in bilirubin level was associated with a decrease in the concentration of urea after treatment in patients with HP-aGDP, however when it increased the changes in bilirubin level either did not occur or they were minor and insignificant.

It seems that the revealed dependence of bilirubin level decrease intensity on the dynamics in urea concentration in the study group of patients is quite natural. It is obvious that the decrease of bilirubin in patients with HP-aGDP is caused by a decrease in the severity of duodenal mucosa inflammation, its swelling, improved function and, as a result improved passage of bile due to performed HP eradication [7]. Thus, changes in urea and bilirubin concentrations can characterize the degree of impairment of function or reparative processes in gastroduodenal region, despite the fact that these parameters indicate different aspects of metabolic disorders.

According to the data of various authors the level of urea both in gastric juice and serum is associated with the activity and prevalence of HP-infection, and hence with the degree 


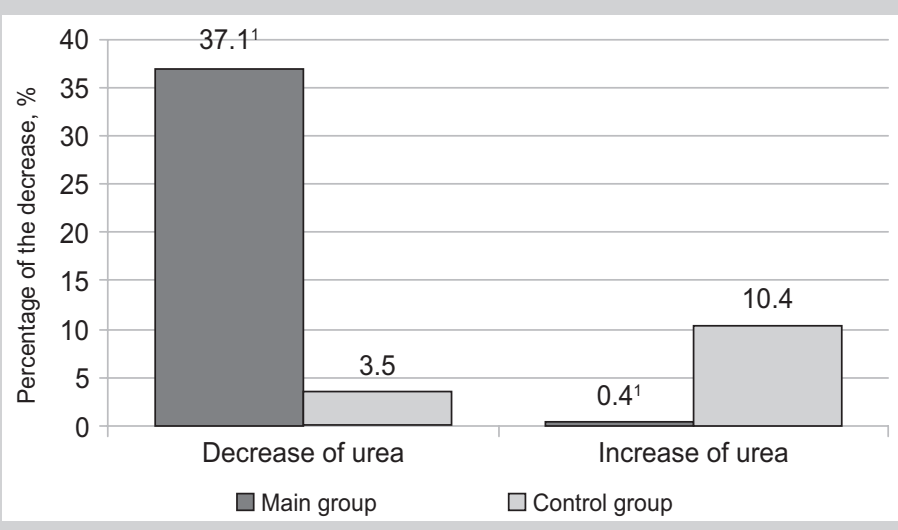

Fig. 3. The percentage of the decrease in the average level of bilirubin in patients of main and contro groups, depending on the decrease or increase of the urea level.

: the difference is statistically significant $(P<0.05)$ between the percentage of the bilirubin level decrease in conditions of decrease or increase of urea in the main group patients.

of inflammatory lesions of gastric or duodenal mucosa [1]. We believe that persistently high level of blood urea after HP eradication in patients of this group can be an indicator of: a) significant mucosal colonization by Helicobacter pylori; b) poor efficacy of eradication treatment. In addition, significant factors influencing the level of urea and bilirubin are the severity of inflammation, swollen and deformed duodenal mucosa, disturbances of contractility, secretory function and secondary disorders of biliary liver function and passage of bile. Accordingly, the reduction of blood urea may indicate the efficacy of eradication therapy and reduction of the inflammation severity.

The relationship between the intensity of HP-infection and impaired biliary excretion, function of gallbladder and ducts is currently distinguished [8]. Therefore, changes in bilirubin in patients with HP-aGDP may be the result of secondary cholestasis, caused by disturbances of duodenal function, duodenostasis, disorder of neuroendocrine function of the stomach and intestines, direct impact of $\mathrm{HP}$ as infectious disturbing factor on mucosa of bile ducts and gallbladder with the initiation of inflammatory process, lithogenesis or incorrectly matched eradication therapy [9]. Thus, bilirubin level in patients with HP-aGDP may also be indicative of related or comorbid diseases of hepatobiliary region, severity of cholestasis and duodenal mucosa inflammation [7].

Consequently, unlike the control group, the dynamics of urea level in patients with HP-aGDP may be indicative of the intensity and prevalence of HP-infection and the efficacy of HP eradication, and blood bilirubin may serve as a reflection of the cholestasis and inflammation of duodenal mucosa severity and their dynamics.

\section{Conclusions}

1. Dynamics of changes in blood urea level in patients with HP-associated gastroduodenal pathology and patients with community acquired pneumonia differed significantly: reduction of urea concentration was observed in significantly greater number of the study group patients, while half of the patients in the control group had an increase of its level by $10.4 \%$. In addition, the reduction of urea in the main group patients was twice as severe and significant. Thus, the reduction of urea may be an additional criterion of HP eradication efficacy.

2. Bilirubin concentration in the blood decreased both in the study and control groups after treatment, but only after $\mathrm{HP}$ eradication its reduction was more marked $(37.1 \%$ vs. $3.5 \%)$ and significant $(P<0.05)$.

3. The intensity of bilirubin decrease in the blood of patients with HP-associated gastroduodenal diseases depended on the dynamics of urea and it was more marked in the settings of its' reduction $(P<0.05)$. Changes in bilirubin level did not depend much on the dynamics of the urea concentration in patients with infectious pneumonia being minor, insignificant and having the opposite direction.

4. Association of bilirubin and urea levels changes was inherent only to patients with HP-associated disorders, indicating the involvement of nitrogen metabolism and liver function in the pathogenesis of given nosology, so monitoring these parameters in patients, especially in the main group, during the eradication has a specific diagnostic and prognostic value.

5. The level of bilirubin in the blood of patients with HP-associated gastroduodenal pathology can reflect the severity of cholestasis, inflammatory lesions of the duodenal mucosa, comorbid hepatobiliary disease.

6 . In addition to the above mentioned, we also determined the involvement of lipid, carbohydrate and protein metabolism, electrolytes, composition and function of blood in the processes of local and systemic inflammation caused by HP and its relationship with adaptive reactions, which generally depended on other individual characteristics of patients in the study group (age, duration of disease, ulcer size, etc.).

It is perspective to examine changes in other metabolic factors in the settings of different dynamics of urea and bilirubin in the blood of patients with HP-associated gastroduodenal pathology for further study of the characteristics of inflammation caused by HP.

\section{References}

[1] Nijevitch, A. A., \& Loguinovskaya, V. V. (2002) Significance of blood urea: gastric ammonia gradient for $\mathrm{H}$. pylori detection in childhood. Digestive diseases and sciences, 47(1), 65-66.

[2] Zahir, F., Rabbani, G., Khan, R. H., Rizvi, S. J., Jamal, M. S., \& Abuzenadah, A. M. (2015) The pharmacological features of bilirubin: the question of the century. Cellular and molecular biology letters, 20(3), 418-447. doi: 10.1515/cmble-2015-0012.

[3] Hamur, H., Duman, H., Demirtas, L., Bakirci, E. M., Durakoglugil, M. E. Degirmenci, H., et al. (2016) Total Bilirubin Levels Predict Subclinical Atherosclerosis in Patients With Prediabetes. Angiology, 67(10), 909-915. doi: 10.1177/0003319716632394.

[4] Akboga, M. K., Canpolat, U., Sahinarslan, A., Alsancak, Y., Nurkoc, S. Aras, D., et al. (2015) Association of serum total bilirubin level with severity of coronary atherosclerosis is linked to systemic inflammation. Atherosclerosis, 240(1), 110-114. doi: 10.1016/j.atherosclerosis. 2015.02.051.

[5] Turfan, M., Duran, M., Poyraz, F., Yayla, C., Akboga, M. K., Sahinarslan, A., et al. (2013) Inverse relationship between serum total bilirubin levels and severity of disease in patients with stable coronary artery disease. Coronary artery disease, 24(1), 29-32. doi: 10.1097/ MCA.0b013e32835b0c13.

[6] Ginhoux, F., \& Jung, S. (2014) Monocytes and macrophages: developmental pathways and tissue homeostasis. Nature reviews. Immunology, 14(6), 392-404. doi: 10.1038/nri3671.

[7] Zhakun, I. B. (2014) Vplyv Helicobacter pylori na stan ta funktsiiu hepatobiliarnoi systemy [The influence of helicobacter pylori infection on the structure and function of the hepatobiliary system]. Hepatolohiia, 4, 6-19. [in Ukrainian]. 
[8] Zhou, D., Guan, W. B., Wang, J. D., Zhang, Y., Gong, W., \& Quan, Z. W. (2013) A comparative study of clinicopathological features between chronic cholecystitis patients with and without Helicobacter pylori infection in gallbladder mucosa. PLoS One, 8(7), e70265. doi: 10.1371/ journal.pone.0070265.

[9] Guraya, S. Y., Ahmad, A. A., El-Ageery, S. M., Hemeg, H. A., Ozbak, H. A., Yousef, K., \& Abdel-Aziz, N. A. (2015) The correlation of Helicobacter Pylori with the development of cholelithiasis and cholecystitis: the results of a prospective clinical study in Saudi Arabia. European review for medical and pharmacological sciences, 19(20), 3873-3880.

\section{Information about authors:}

Zhakun I. B., MD, PhD, Associate Professor, Department of Internal Medicine No. 2, Danylo Halytsky Lviv National Medical University, Ukraine.

Sorokopud 0. 0., MD, PhD, Associate Professor, Department of Internal Medicine No. 2, Danylo Halytsky Lviv National Medical University, Ukraine.

Strilchuk L. M., MD, PhD, Assistant Professor, Department of Therapy No. 1 and Medical Diagnostic FPGE, Danylo Halytsky Lviv National Medical University, Ukraine.

Kit Z. M., MD, PhD, Associate Professor, Department of Family Medicine, Danylo Halytsky Lviv National Medical University, Ukraine.

Kondratyuk M. 0., MD, PhD, Associate Professor, Department of Internal Medicine No. 2, Danylo Halytsky Lviv National Medical University, Ukraine.

\section{Відомості про авторів:}

Жакун І. Б., канА. меА. наук, Аоцент каф. внутрішньо медицини № 2, Аьвівський національний медичний університет імені Аанила Галицького, Україна.

Сорокопуд О. О., канд. меА. наук, доцент каф. внутрішньої меАицини № 2, ^ьвівський національний меАичний університет імені Аанияа Галицького, Україна.

Стрільчук ^. М., канА. меА. наук, асистент каф. терапії № 1 та еАичної Аіагностики ФПАО, Аьвівський національний медичний університет імені Аанила Галицького, Україна Кіт 3. М., канА. меА. наук, Аоцент каф. сімейної меАицини, ^ьвівський національний медичний університет імені Аанила Галицького, Україна.

КонАратюк М. О., канА. меА. наук, Аоцент каф. внутрішньої меАицини № 2, Аьвівський національний меАичний університет імені Аанила Галицького, Україна.

\section{Сведения об авторах:}

Жакун И. Б., канА. меА. наук, Аоцент каф. внутренней медицины № 2, Аьвовский национальный медицинский университет имени Аанияа Галицкого, Украина.

Сорокопуд Е. А., канА. меА. наук, Аоцент каф. внутренней меАицины № 2, Аьвовский национальный меАицинский университет имени Аанила Галицкого, Украина.

Стрильчук $\Lambda$. Н., канА. меА. наук, ассистент каф. терапии № 1 и меАицинской Аиагностики ФПАО, Аьвовский национальный медицинский университет имени Аанила Галицкого, Украина. Кит 3. М., канА. меА. наук, Аоцент каф. семейной меАицины, Аьвовский национальный медицинский университет имени Аанила Галицкого, Украина.

Кондратюк М. О., канА. меА. наук, Аоцент каф. внутренней меАицины № 2, Аьвовский национальный меАицинский университет имени Аанила Галицкого, Украина.

Конфиікт інтересів: віАсутній.

Conflicts of Interest: authors have no conflict of interest to declare.

Надійшло Ао редакції / Received: 29.05.2017

Після Аоопрацювання / Revised: 08.06.2017

Прийнято Ао Аруку / Accepted: 08.09.2017 